\title{
Who killed schoolgirl cricket? The Women's Cricket Association and the death of an opportunity, 1945-1960. ${ }^{1}$
}

\begin{abstract}
This article examines the reasons behind the decline of schoolgirl cricket in the years between 1945 and 1960 . It considers the impact of the Education Act 1944 and 'secondary education for all' on girls' physical education in general, focusing on why certain sports, in particular cricket, were not widely introduced into the new secondary modern and grammar schools. The outreach programme of the Women's Cricket Association, the governing body of women's cricket, to these new schools is considered alongside the problem of equipment and pitch shortages. Ultimately, blame for schoolgirl cricket's failure to become entrenched within the English education system is placed upon the attitudes of teachers and Local Education Authorities towards girls' cricket at this time; they considered the sport unsuitable for female pupils. Overall, the article serves as an historical case study of gendered physical education in action.
\end{abstract}

Keywords: Women's education, physical education, cricket, gender.

In the 1970s the Sports Council declared that women's cricket, as a sport, was 'dying'. ${ }^{2}$ By 1970 only 66 clubs were affiliated to the governing body of the sport, the Women's Cricket Association (WCA), compared with 200 in 1955. A key factor in this decline was the failure of the WCA to revitalise its membership in the postwar period by attracting young members; at its lowest point, just 46 schools were affiliated. ${ }^{3}$ Evidently, cricket for schoolgirls had not become a popular choice of activity.

It has become a truism in research on Physical Education (PE) to suggest that the British system has historically sustained and reproduced ideologies of sexual difference. Sheila Scraton is a key proponent of this view:

Schools as important institutions serve to reproduce the status quo in relation to the capitalist mode of production and male-female power relations...Physical education as an aspect of schooling fits into this process both in terms of its relationship to a sexual division of leisure in society and the reinforcement of patriarchal power relations. $^{4}$

More recent work on the subject has reinforced this argument. ${ }^{5}$ The inclusion of team games in the curriculum, in particular, has been seen as a key way of encouraging acceptable 'feminine' behaviour, by 'limiting girls' access to those sports which stressed endurance, strength or physical contact'. ${ }^{6}$ Thus, within educational institutions, girls have been encouraged to participate in netball and hockey, whilst football and rugby have remained masculine domains.

However, despite the prevailing acceptance of this view, many of its premises are based on generalisations, without detailed historical evidence to support their conclusions. Hargreaves' history of women's sport, for example, only briefly considers schoolgirl games, and her accounts rely heavily on a few oral history reminiscences and official pronouncements by the Board (later

I thank Peter Catterall for his helpful comments on an earlier draft of this article.

Jack Williams, 'Cricket', in Tony Mason (ed.), Sport in Britain: a social history (Cambridge: CUP, 1989$): 141$.

Women's Cricket Association, 'Yearbook 1955' and 'Yearbook 1970', Women's Cricket Associates,

http://www.womenscrickethistory.org/ (accessed January 27 2012).

4 Sheila Scraton, Shaping up to Womanhood: gender and girls' physical education (Milton Keynes: Open University Press, 1992): 18.

5 See for example Jennifer Hargreaves, Sporting Females: critical issues in the history and sociology of women's sports (London: Routledge, 1994), and Dawn Penney and John Evans, Gender and Physical Education:

Contemporary Issues and Future Directions (London: Routledge, 2002).

6 Scraton, Shaping up to Womanhood: 28. 
Ministry) of Education. ${ }^{7}$ Her conclusions are thus subject to sampling error and tend towards an oversimplification of the varied experiences of those participating in PE in the interwar and postwar period. More general histories of sport in the UK have focused almost exclusively on the experiences of sport in adulthood; Holt and Mason state simply that '[c]omprehensive education did not make sport a priority'. ${ }^{8}$

There has been some relevant work conducted on PE in state schools in the interwar period. McIntosh, Welshman and Skillen have all highlighted the increasing involvement of the Board of Education in PE in the years from 1900. ${ }^{9}$ Attempts were made in these years to standardise provision of PE in the state sector, through the introduction of syllabi and the passing of legislation including the Physical Training and Recreation Act of 1937, which sought to provide for the establishment of centres to encourage physical recreation. Lessons which had originally centred largely around military drill were becoming much more focused on recreative aspects and the playing of team games. However, prior to the war most working-class girls left school at fourteen, and it was recognised that facilities and finances, equipment and pitches were extremely limited. Welshman highlights 'the great gulf that could exist between rhetoric and reality' up to $1939 .{ }^{10}$

Much less has been written on the post-1944 Education Act period. ${ }^{11}$ In order to substantiate the claim that PE is inherently gendered as a result of its historical development, more in-depth studies of these years are necessary. The discussion that follows considers PE in the immediate postwar period in some detail, with a focus on the Women's Cricket Association. It was in these years that those in authority experienced their first opportunity to introduce PE at secondary-level to a mass market. The 1944 Education Act stated:

It shall be the duty of every local education authority to secure that there are adequate facilities for recreation and social and physical training, and for that purpose a local education authority may establish, maintain and manage camps, holiday classes, playing fields, play centres, playgrounds, gymnasiums, and swimming baths. ${ }^{12}$

For the first time, physical education provision became an obligatory responsibility of local education authorities (LEAs); this differed from the permissive legislation of the interwar years. There was therefore huge potential to introduce particular sports to the influx of girls (and boys) into secondary schools. Additionally, because many of the new secondary schools were coeducational, there was an unprecedented opportunity to introduce sports which had previously only been played at single-sex boys' schools to their female classmates. This was a key moment if schoolgirl cricket was ever to become entrenched within the English education system.

This article seeks to understand why, even in a period of 'secondary education for all', this did not occur. It asks why, right from the onset of the tripartite system, some sports were encouraged above others in the school curriculum for girls, and why some, like cricket, were always excluded from consideration. In doing so, it builds on the work of those like Skillen who have highlighted the focus on gymnastics, hockey, netball and swimming in interwar syllabi for girls as a result of these activities being seen as 'appropriate and suitable for young sportswomen' due to the

\footnotetext{
Hargreaves, Sporting Females: 120-122, 152-154.

Richard Holt and Tony Mason, Sport in Britain, 1945-2000 (Oxford: OUP, 2000): 17.

9 Peter McIntosh, Physical Education in England since 1800 (London: Camelot Press, 1952); John Welshman, 'Physical Culture and Sport in British Schools, 1900-40', International Journal of the History of Sport 15:1 (1998); John Welshman, 'Physical Education and the School Medical Service in England and Wales, 1907-39', Social History of Medicine 9:1 (1996); Fiona Skillen, ' “A sound system of physical training”: the development of PE in interwar Scotland', History of Education 38:3 (2009).

10 Welshman, 'PE and the School Medical Service': 48.

11 Exceptions are McIntosh, Physical Education in England, and Sheila Fletcher, Women First: the female tradition in English physical education (London: Athlone Press, 1984).

12 Education Act 1944, 7 and 8 Geo 6 c. 31 (London: HMSO): s.53(1).
} 
restraints they placed upon them. ${ }^{13}$ Here, cricket for girls is used as a case study. It provides an interesting example because, unlike football and rugby, it is a non-contact sport and not overtly aggressive, or 'masculine'. Indeed, those in the WCA had always drawn attention to its graceful and 'feminine' aspects. ${ }^{14}$ It had also long been played by women: the first recorded match dated back to 1745, and middle-class females had increasingly taken up the sport during the nineteenth century. ${ }^{15}$ Why, therefore, was the opportunity to introduce cricket to a new market, working-class girls, squandered so comprehensively? Was it, as might be claimed, a case of girls themselves rejecting the sport, or did an untapped demand for girl's cricket exist?

The first section considers the established argument that the WCA, the governing body of women's cricket, can be blamed for the decline of schoolgirl cricket because of their supposed elitism. The attitudes of the organisation, as demonstrated in Association minutes and the WCA's official magazine, will be considered alongside the school affiliation figures which have been used to indict them. The second section considers the alternative argument that facilities within state schools were insufficient for school cricket to ever be a viable option in the new secondary modern schools, utilising official Ministry of Education pronouncements on and investigations into PE during this period. It is argued that cricket was not in fact outside the financial and spatial remit of the secondary modern school. Ultimately, the final section seeks to demonstrate, through the combined use of Ministry of Education and WCA documentation, that attitudes to schoolgirl cricket from the top-down remained hostile. The article indicates the need to consider attitudes to PE in schools from the perspective of both government and governing body, something which has not been done previously. It supports the argument that PE in schools helped perpetuate traditional gender roles, demonstrating the culpability of those within education in neglecting to promote cricket for girls, and providing a key case study approach to understanding the gendered history of PE within the English system.

\section{'School-leavers constitute the Suez Canal for the WCA'}

The WCA had been formed in 1926 by a group of female hockey players who wanted a team game to play in the summer months, and their efforts in the years up to 1939 had enabled cricket for women to take off on a national scale. By 1938 the Association had grown into a governing body with 20 county associations, 105 clubs and 82 schools affiliated. International women's cricket had been initiated, with the WCA sending a team to Australia and New Zealand in 1934-5, and a return visit being made by the Australians in 1937. A moderate amount of press coverage and public interest had been attracted through the WCA's publicity efforts, including the production of their own cricket film, and some male county cricketing authorities had proved keen to host annual representative matches. ${ }^{16}$ There was much to be proud of.

In the years before 1939, however, cricket had been concentrated in large female public schools like Roedean, St Leonard's and Wycombe Abbey, as well as the High Schools run by the Girls Public Day School Trust (GPDST): schools which were pioneers in promoting physical activity for women. ${ }^{17}$ In the state sector, the Board of Education recommended netball and rounders as the chief school games for girls. An official policy document in 1927 stated that: 'Hockey and lacrosse do not as a rule come within the scope of senior elementary school classes owing to the amount of time required to master the difficulties of technique, the expense of a specially prepared

13 Skillen, “A sound system of physical training”: 413.

14 See for example Marjorie Pollard, Cricket for Women and Girls (London: Hutchinson and Co, 1934): 13-14, 65.

15 Kathleen McCrone, Sport and the physical emancipation of English women (London: Routledge, 1988), chapter 5.

16 See Jack Williams, Cricket and England: a social and cultural history of the interwar years (London: Frank Cass, 1999): 92-111.

17 McCrone, Sport and the physical emancipation of English women: 60-90. 
grass surface, and the provision of sufficiently good equipment. Cricket presents even greater difficulties...unless suitable conditions are available, the games are not worth attempting because they cannot be played satisfactorily'. ${ }^{18}$

Thus, of the 82 affiliated schools affiliated to the WCA in 1938, 63 or approximately $75 \%$ were independent schools; only 19 were wholly state-maintained. This has led some historians to accuse the WCA of elitism and of stifling its own development. Jack Williams' argument is that

Women's cricket was controlled by those from economically privileged groups...[the WCA] tried to organise the women's game in accordance with the values of men's cricket clubs for those from the wealthier classes in the south of England. ${ }^{19}$

Additionally, Martin Francis has asserted that 'Women's cricket...failed to attract interest outside the products of a few elite private schools'. ${ }^{20}$ These explanations do not apparently allow for any development of cricket in the new secondary modern schools. Not only, according to these interpretations, was the WCA an elitist organisation, but state school girls themselves showed no interest in the sport. It is necessary to challenge these kinds of statement not just because of their factual inaccuracy, but because they perpetuate the sense that cricket does not belong in state schools - a factor which has played no small part in its decline as a school sport over the past half century. $^{21}$

In fact, a detailed examination of the ways in which the WCA reacted to the new system of 'secondary education for all' very quickly reveals its members to have been exceptionally concerned to increase school affiliations and thereby inject new blood into their association. During their 1952 AGM, it was recognised that 'the present danger lay in being content to remain in the same old rut...More coaching facilities were needed for young people wishing to learn the game'. ${ }^{22}$ In 1947 a Schools Sub-Committee was formed:

the first object should be to form groups of schoolgirl cricketers in as many areas as possible. Miss Riley suggested that arrangements might be made for prominent members of the WCA to visit all affiliated, and any possible non-affiliated schools, to speak to the Games Mistresses and girls, if possible, and distribute suitable WCA literature, not forgetting the film. ${ }^{23}$

Letters were sent to all schools which had been affiliated pre-war inviting reaffiliation, and to all County Secretaries recommending the formation of groups of school-girl cricketers and the organisation of school cricket rallies to provide group coaching. An 'advantages of membership' leaflet was distributed which cited coaching facilities, reduced admission to territorial and international women's matches, free literature and the WCA's annual festival of cricket, Colwall Cricket Week, as reasons why schools should affiliate to the WCA. ${ }^{24}$ An annual 'Holiday Coaching Week' was instituted, targeting young players, and partly financed by the WCA itself. In conjunction

18 Board of Education, Supplement to 1919 Syllabus of Physical Training for Older Girls (London: HMSO, 1927$)$ : 33.

19 Jack Williams, Cricket and England: 100.

20 Martin Francis, 'Leisure and Popular Culture', in Ina Zweiniger-Bargielowska (ed.), Women in Twentieth-Century Britain (Harlow: Longman, 2001): 237.

21 On the decline of cricket in state schools, see The Telegraph, 20 May 2010. There is evidence that state school teachers have been relucant to introduce cricket even among male pupils due to concerns about its unsuitability in this context. See for example School Sport Magazine, July 1976.

22 Women's Cricket Association, 'Yearbook 1952: AGM minutes', Women's Cricket Associates, http://www.womenscrickethistory.org/ (accessed January 27 2012).

23 WCA Executive Committee minutes, 14 November 1947, WCA Archive, Lancashire. Elizabeth Riley was a Territorial Representative for the East Territory and a Kent player.

24 Colwall is a village in Herefordshire. The WCA's Cricket Week was held there because this was where the founders of the Association had been holidaying when they made the decision to form the WCA; the village was referred to as the 'birthplace' of women's cricket. 
with the Central Council of Physical Recreation, WCA volunteers ran numerous coaching courses around the country. A key motivating factor for schools to affiliate was the significantly reduced annual affiliation fee, which in 1945 was just five shillings per school and two shillings and sixpence for schoolgirls, compared with $£ 5$ for an adult member of an affiliated club. ${ }^{25}$ Liasing with teaching staff was also an important part of the WCA's strategy: in 1950 they stated that their policy 'had been that of pleading with colleges, Physical Training Organisers and Headmistresses to include cricket in their curricula. Where it has been possible, cricket has been included'. ${ }^{26}$

The minutes of grassroots women's cricket clubs indicate that local-level initiatives were also being pursued. The Redoubtables Women's Cricket Club, based in Surrey and with an average membership of 25, provides a good example of how women's clubs were seeking to engage with schoolgirls in their localities. The members paid for Joan Hawes, a promising youngster (who went on to play for England) to attend Cricket Week in 1952, and in 1959 they paid for two junior club members to attend a Surrey Coaching course. In 1957 they lent their ground at Beddington Park to Surrey WCA for the County Schoolgirl Trials, without charge. They also regularly wrote to all schools in Surrey, requesting the names of girls interested in cricket who would be leaving at the end of the school year. ${ }^{27}$ Redoubtables were a well-off club located in an affluent area and a lack of research into grassroots women's cricket means it is not yet possible to make conclusions about how typical their activities may have been. Nonetheless, the fact that they were following WCA directives suggests that their efforts were probably commonly replicated elsewhere around the country.

Some of the WCA's resources were, it must be admitted, concentrated in continued outreach to the public schools, as evidenced by their magazines, which report WCA visits during the 1950s in an attempt to encourage those with a long-established tradition to remain enthusiastic about their cricket. Both Cheltenham Ladies College and Wycombe Abbey, for example, entertained the Australian players to lunch during their 1951 tour 'and subsequently followed their fortunes at the second and final test matches at Worcester and the Oval with great interest'. ${ }^{28}$ But what was new about the postwar period, and particularly striking, was the fact that efforts were no longer exclusively focused on the public or even the older grammar schools. In Women's Cricket magazine, the official magazine of the WCA, the organisers of central schoolgirl coaching sessions reported numerous successes in attracting girls from secondary modern schools to attend. Kent's scheme of 1948 attracted 123 girls from local secondary modern and grammar schools. Similarly Warwickshire's 1949 coaching session attracted 83 girls after typed circulars were sent to all local secondary modern and grammar schools. In Nottinghamshire, the 1950 Schoolgirls' Coaching Scheme was open only to girls from Nottingham's grammar and private schools, but by 1951 it included two secondary modern schools. ${ }^{29}$ It is difficult to know what the exact make-up of these events would have been but it does show at least some level of interest from girls at secondary modern schools where the opportunity to play cricket was available.

Members of the Physical Eduction Inspectorate established by the Ministry of Education after the war were quick to blame governing bodies of sport for a lack of engagement with schools, arguing that these bodies were often reluctant to forge links between their own activities and those occurring within education. In 1961, the Inspectorate agreed

that the shortage of facilities played into the hands of those people (including some governing bodies of sport) who were only interested in using the most able performers ...Governing bodies of sport were not interested...in

\footnotetext{
25 Women's Cricket Association, 'Yearbook 1946: WCA Rules', Women's Cricket Associates, http://www.womenscrickethistory.org/ (accessed January 27 2012).

26 WCA Executive Committee minutes, 9 December 1950, WCA Archive, Lancashire.

27 Redoubtables AGM and Executive Committee minutes, 1945-60, private collection, Wallington, Surrey.

28 Cheltenham Ladies College Magazine, 1951: 91. Wycombe Abbey Gazette, December 1951: 86.

29 Women's Cricket, 29 May 1948, 20 August 1949, 14 June 1951.
} 
this [less able] section of the schools' population. ${ }^{30}$

Certainly in the case of the WCA this accusation is patently untrue and unfair. All coaching courses were open to absolute beginners: adult female cricketers were attempting outreach, regardless of ability.

The WCA were quite clear as to why schoolgirl outreach as such an important priority. An August 1956 editorial of their official magazine, Women's Cricket, suggested that

School-leavers constitute the Suez Canal for the WCA. They are our life-blood and vital to us if we are to survive... probably our biggest liability is the relatively small entry of school-leavers into the clubs.... What can we do more to encourage the younger members?...We must consider the formation and organisation of AfterSchool clubs, junior sections, reduced club affiliation fees for youngsters, suitable publicity, energetic and enthusiastic physical education staff and many other possible remedies. And we must act. ${ }^{31}$

Given earlier events of that year, this reference to the Suez Canal is rather amusing in retrospect. Nonetheless, quotations like this one absolutely support the fact that the WCA were, as a whole, very concerned with the reinvigoration of their membership and were willing to go to great lengths to ensure that new members were made welcome.

Yet, overall, how successful were these efforts at engagement with the new state secondary schools? One measure of success must surely be the WCA's school affiliation figures for the postwar years. These do seem to suggest only limited success at outreach.

\section{TABLE 1}

As can be seen from Table 1, though grammar school affiliations had increased by 1960, there continued to be only tiny numbers of comprehensive schools affiliated, and no secondary modern schools at all. The figures for grammar schools were better: the number had risen from 33 in 1950 to 43 in 1960. However, many of these were older grammar schools, generally located in more affluent areas, some of which had merely continued their pre-war affiliations. ${ }^{32}$ This compared unfavourably with other sports. By 1950, the All England Women's Hockey Association had 886 school affiliations (compared with 695 schools in 1939), many of which were secondary modern schools. ${ }^{33}$ The Northumberland representative of the All England Netball Association reported that in 1939 a mere 10 schools had been affiliated, but by 1951 the figures were 14 grammar schools and 61 secondary modern schools. This appears to have been fairly typical. ${ }^{34}$ If, as I have been arguing here, WCA efforts were so exhaustive, why were their attempts to increase state school affiliations such a failure? The concluding two sections of the article will address this question.

\section{'In many Modern Schools the work is crippled because of the poor facilities'}

The educational policy of the Attlee governments has recently been described as 'the most important

30 PE Inspectorate meeting, 9 and 10 January 1961, ED 118/16, The National Archives, Public Record Office, Kew (hereafter TNA: PRO).

31 Women's Cricket, 31 August 1956.

32 At least 23 were grammar schools dating from before 1945. Nine had been affiliated to the WCA before the war.

33 'AEWHA Report, 1950', ED 169/36, TNA: PRO.

34 All England Netball Association, The Silver Jubilee Book. Netball 1901-1951 (Manchester: AENA, 1951): 15-25. 
gap in Labour's egalitarianism'; ${ }^{35}$ from their beginnings, the new secondary modern schools were often hampered by a lack of funds, and a key element of this was PE. The 1944 Education Act was supposed to ensure that no schools were without a playing field, but many school buildings remained out of date. John Newsom's The Education of Girls, published in 1948, reported on the ways in which the English education system differentiated between boys and girls, and made recommendations regarding the future of female secondary education. His report touched on the problem of PE, stating:

Many of these [secondary modern] schools have no playing space other than the tarmac of the playground, the girls never handle a tennis racquet or a hockey stick...[they spend] an hour in the playground practising netball, under difficulties since some 200 other girls are milling around in various forms of unorganized play and a good deal of shouting and laughter. ${ }^{36}$

There were two other key problems. Firstly, it was recognised that the limited amount of time given to PE in schools - often just two 30-minute periods a week - rendered the development of the skills needed for some games out of reach. ${ }^{37}$ Additionally, there remained a severely limited supply of specialist teachers in both grammar and modern schools. A sample of staffing for PE taken from eight counties and ten boroughs in April 1949 uncovered an average teaching shortfall of 64\% and $61.5 \%$ in the grammar and modern schools respectively. ${ }^{38}$ The situation did improve over time. However, the Newsom Report of 1963 still found that less than a third of the schools sampled had playing field provision 'up to the standard prescribed by regulations' and '[m]any lacked an adequate gymnasium'. ${ }^{39}$

The Ministry of Education did not produce any new PE syllabi for secondary schools in this period. By default, therefore, the new schools relied on the 1933 Board of Education's Syllabus of Physical Training for Schools, which was still in large demand after 1945 and was reprinted in 1949 unaltered. ${ }^{40}$ This stated that, for girls,

Netball has proved itself a remarkably suitable game for playgrounds...Shinty, Handball, Touch and Pass, Rugby touch, Rounders and Stoolball are team games which can be brought to a high pitch of skill, and if played well, will provide a useful foundation for any games the girls may take up on leaving school. Cricket presents considerable difficulties owing to the cost of good pitches. It may be possible in certain schools to secure both the services of a teacher who is a first class coach and the right facilities for play, but unless suitable conditions are available, the game should not be attempted. Lacrosse with its difficult preliminary technique and expensive equipment does not yet come within the scope of elementary schools. Hockey is being played with increasing success in certain districts where sufficient level pitches can be secured. $^{41}$

In the years after 1945, according to the Physical Education Inspectorate, netball and rounders remained important school games for girls, but hockey and tennis also became increasingly widespread. Given the above conditions, it might be argued that any form of cricket continued to be almost impossible: the Board of Education had implied that it required a school to pay for both new equipment and the upkeep of a pitch. The argument is not this straightforward, however. Firstly, it appears that where money was available for new PE facilities, it was often disproportionately allocated to facilities for boys. A PE Inspectorate Memorandum dated 2 April 1953 stated: 'In many Modern Schools the work is crippled because of the poor facilities, and in

35 Paul Addison, No Turning Back. The Peacetime Revolutions of Post-War Britain (Oxford: OUP, 2010 ): 40.

36 John Newsom, The Education of Girls (London: Faber and Faber, 1948): 89-91.

37 Memo, 'Physical Education in Secondary Modern Schools', 2 April 1953, ED 158/115, TNA: PRO.

38 Memo, 'Supply of specialist teachers in grammar and modern schools', March 1951, ED 158/114, TNA: PRO.

39 Newsom Report (London: HMSO, 1963), chapter 17.

40 PE Inspectorate meeting, 24 and 25 April 1947, ED 158/114, TNA: PRO.

41 Board of Education, Syllabus of Physical Training for Schools (London: HMSO, 1933; reprinted 1949): 39. Italics in original. 
mixed schools the situation is usually worse... Very often the girls have no playing field' ${ }^{42}$ Another memo from the same year on the situation in the South of England demonstrated that this was becoming a concern by including a category of 'equal consideration [for] boys and girls' in measurement of new gymnasia. In this case, it was found that Wimbourne County Secondary Modern in Dorset did not have equal provision (though the other ten schools surveyed stated that they did). Newsom also recognised this as a problem. Comparing the lives of the typical secondary modern pupils his 1963 Report recognised that 'Mary...is a good deal less likely than John to play for a school team...because games play a less important part for girls than for boys...There are in fact in the sample roughly twice as many boys as girls who play regularly for a school team'. ${ }^{43}$

Secondly, limited funds would have meant prioritising, and for girls, it is obvious that certain sports never took precedence. The PE Inspectorate found that in 1959, the typical PE programme for girls always included gymnastics, often involved dance, and was comprised of hockey, netball, tennis and swimming 'where possible'. Athletics was unusual in girls' schools and other activities were 'occasional'; cricket was not even mentioned by name. The Inspectorate seemed to agree that this order of preference was advisable, commenting: 'The following ought to be included in the first year - gymnastics, dance, hockey or lacrosse, swimming...gymnastics and dance...should be a constant factor in the programme...It is difficult to know how far girls really enjoy athletics'. ${ }^{44}$ Another priority was swimming; the minutes of the Inspectorate indicate a push in the postwar years to make this an activity available to all secondary school children, despite the obvious difficulties with having to travel to pools away from school premises. This had been a focus pre-war too: in the 1933 Syllabus, the Board of Education stated that their aim was for 'every school...[to] make provision for the inclusion of this subject in its curriculum'. ${ }^{45}$ Swimming pool usage, the upkeep of hockey pitches, new tennis courts and the corresponding equipment required were not cheap, but schools and education authorities were prepared to spend money on them, or at the very least pay to hire out the facilities at local parks. Additionally McIntosh reports that it was in these years that many LEAs introduced 'outdoor activities such as canoeing, sailing, climbing and outdoor adventure in general...for the first time'. ${ }^{46}$

Cricket was therefore not necessarily beyond the budgetary constraints of state secondary schools. Indeed, it was being played and encouraged at some secondary modern schools. Girls at the Hayward School, Bolton, attended joint practices on the pitch they shared with the neighbouring technical and grammar schools. Girls from all three of these schools were invited to join a team which regularly played after school hours. Eventually the headmistress agreed to include cricket in the games curriculum of the school. ${ }^{47}$ Some secondary modern schools could even offer facilities to local clubs who were struggling for resources. At Dorchester Secondary Modern School in 1955 the newly-formed Dorchester Women's Cricket Club agreed to hold its practices on school premises, due largely to the fact that its Secretary was a teacher at the school. A similar situation occurred with Norfolk WCA, who used the Secondary Modern School at Fakenham for meetings. ${ }^{48}$ A pitch was not necessarily a requirement, either. One schoolgirl reported on what could be achieved even with scarce resources, if the teaching staff were willing to cooperate:

I was lucky enough to be at a school which is affiliated to the WCA. The headmistress is vice-chairman of the association and takes a keen interest in games. Girls at our school have one cricket lesson a week in their second year. They are taught first of all to field and bowl, using a hard ball...This is then followed by mass

\footnotetext{
42 Memo, 'Physical Education in Secondary Schools', 2 April 1953, ED 158/115, TNA: PRO. My italics.

43 Newsom Report, chapter 22.

44 PE Inspectorate meeting, 21 and 22 September 1959, ED 118/16, TNA: PRO.

45 Board of Education, Syllabus of Physical Training: 63.

46 McIntosh, Physical Education in England: 264.

47 Women's Cricket, 1 May 1959.

48 Ibid., 10 June 1955 and 14 May 1954.
} 
coaching in all the basic batting strokes. ${ }^{49}$

Her school did not possess its own pitch but was able to introduce cricket to its pupils nonetheless. Ultimately, as the WCA indicated in its engagement with local schools that did not possess pitches, a lot could be achieved if teaching staff were enthusiastic and prepared to improvise with less than ideal equipment. As one WCA member wrote, 'If a school has space to play rounders, it should be possible to play cricket bat and ball games in the same area. Why not rounders with a cricket bat and ball and a pitched ball! ${ }^{50}$

Cricket was in fact becoming much more readily available to boys in state schools, often in the same schools attended by girls, thanks to effective liaison between the Marylebone Cricket Club (MCC, the governing body of men's cricket in Britain) and the LEAs. There was some recognition in the years after the war that the way to improve the standard of English Test players was to provide better facilities for boys, particularly those at state schools. Thus in 1948, following the 4-0 Ashes defeat which had been dogged by selection issues, the MCC announced an enquiry into youth cricket. Chaired by H.S. Altham, treasurer and later president of the MCC, the committee's remit was 'to examine the problems concerned with the learning and playing of cricket by the youth of the country between the age of eleven and the time of their entry into National Service', and 'to consider how best to foster their enthusiasm for our national game by providing them with wider opportunities for reaping its benefits'. ${ }^{51}$ A whole host of bodies were represented, among them the WCA by the England captain Molly Hide. This was the first time women had ever been represented on an MCC committee.

In 1950 the committee's recommendations were published. Their main proposal was the establishment of a national organisation, controlled by the MCC, to coordinate coaching around the country, through new Area Youth Cricket Councils. ${ }^{52}$ Two years later, the MCC Youth Cricket Association was formed and by 1957, 34 Area Youth Councils had been established, covering every first-class county and working in collaboration with their LEAs. ${ }^{53}$ This work has been described by Holt and Mason as an 'innovation' in postwar British sport. ${ }^{54}$

Crucially, the remit of the committee was to consider the situation for boys and girls and in its concluding remarks the report stated:

\begin{abstract}
We understand that this is the first time that a body of so widely representative a nature has been called together by the MCC, and we wish to record our great satisfaction in the fact that at no stage was any real divergence of view apparent, despite the variety and complexity of the issues involved, and the many interests affected. This unanimity appears to us to emphasise the general recognition of the urgency of the problem and of the widespread desire to try and find a solution. ${ }^{55}$
\end{abstract}

By 1956, 112 out of 325 secondary modern schools in London were coeducational, a situation being replicated across the country in the postwar period. ${ }^{56}$ There was therefore clearly a market for the introduction of cricket into these new mixed schools, where it could be played by both boys and girls in a way that maximised efficient use of resources. Indeed, four coeducational schools were affiliated to the WCA in 1960, all of which encouraged the sport for both male and female pupils. Yet the majority of affiliated state schools were single-sex, with the implication that

\footnotetext{
John St John (ed.), The MCC Book for the Young Cricketer (London: the Naldrett Press, 1951): 52.

50 Women's Cricket, 5 September 1958.

51 Marylebone Cricket Club, Report of the Cricket Enquiry Committee (London: MCC, 1950): 1.

52 Ibid.: 12

53 Derek Birley, A Social History of English Cricket (London: Aurum Press Ltd, 1999; reprinted 2003): 278.

54 Holt and Mason, Sport in Britain: 21.

55 MCC, Report of the Cricket Enquiry Committee: 23.

56 Directory of Modern Secondary Schools 1956 (London: School Government Publishing Company, 1956): 35-46.
} 
most coeducational state schools where boys played cricket had not introduced it for girls. ${ }^{57}$ The problem was that in practice, while cricket for boys was perceived as important, there was still only a limited recognition - as we have seen above - that girls might also want to play while at state schools. By 1955 only three counties had invited female representatives to take part in their Youth Advisory Committees. ${ }^{58}$ Despite WCA efforts, two of these committees had actively refused to appoint women, and the others do not appear to have responded to WCA requests. ${ }^{59}$ Cricket for boys was therefore able to expand, while it remained difficult for girls to participate.

It appears that a simple lack of facilities does not explain the absence of schoolgirl cricket from state-maintained schools in this period. In fact, we must look in more detail at the attitudes of both teachers and LEAs to discover why certain sports were encouraged above others. The next section examines these two groups in more detail.

\section{'Girls will not enjoy a game in which they have neither aptitude nor interest'}

Given the lack of guidance from central government about precisely which sports should be encouraged at secondary level in the years after 1945, the attitudes of individual teachers and LEAs were often crucial in determining what, in practice, occurred during PE lessons. By considering WCA comments on the attitudes of these groups to schoolgirl cricket alongside the statements teachers and LEAs themselves made, it is possible to ascertain why cricket was not a favoured sport for girls. The evidence produced below supports the argument that PE developed after the war in a way which reinforced and reproduced traditional gender roles.

Expenditure by LEAs on recreation and physical training increased from $£ 2,239,000$ in $1946-7$ to $£ 3,601,000$ in 1950-51; by 1960, a government report indicated that this was a long-term trend, as spending was 50\% greater in this area than it had been in $1945 .{ }^{60}$ The newly-created Ministry of Education offered grants towards the salaries of national coaches in sport, as well as continuing to grant-aid voluntary youth organisations and work closely with the Central Council of Physical Recreation. For example, by 1952 the Ministry had awarded £2,896 to the Amateur Athletics Association, $£ 1,413$ to the Lawn Tennis Association, and $£ 410$ to the All England Women's Hockey Association. ${ }^{61}$ The Ministry also offered grants for coaching, and to specific schools for the purchase of equipment to be used in PE lessons.

Yet the Ministry do not appear to have been favourably disposed to the WCA as a body. In 1948 the WCA applied for funding for five part-time coaches to be spread over the country, each to receive a salary of $£ 80$ a year and visit affiliated and non-affiliated schools during the summer months, while organising indoor coaching during the winter. But the application was turned down and the WCA was forced to evolve an independent scheme of its own, establishing a panel of unpaid, volunteer coaches. ${ }^{62}$ WCA minutes also report examples of education authorities turning down applications for grants made by schools to purchase cricketing equipment. They appear to have felt that the money would be better spent elsewhere. ${ }^{63}$ A prevailing negative attitude is reinforced by a report in Women's Cricket that some female teachers considered it unwise to mention their background in cricket when applying for teaching jobs: 'it isn't safe', one was quoted

57 By 1960 at least 36 of the state schools affiliated to the WCA were single-sex. See Women's Cricket Association, 'Yearbook 1960', Women's Cricket Associates, http://www.womenscrickethistory.org/ (accessed January 272012 ).

These were Yorkshire, Sussex and Surrey. See Women's Cricket, 4 May 1951.

WCA Executive Committee minutes, 27 October 1950 and 9 December 1950, WCA Archive, Lancashire.

60 Ministry of Education, The Youth Service in England and Wales (London: HMSO, 1960): 8.

61 PE Inspectorate meeting, 18 and 19 December 1952, ED 158/15, TNA: PRO.

62 WCA Executive Committee minutes, 17 January 1948 and 21 May 1948, WCA Archive, Lancashire.

63 See for example WCA Executive Committee minutes, 21 June 1948, WCA Archive, Lancashire. 
as saying in Women's Cricket in 1953. 'Education authorities don't like it'. ${ }^{64}$ Most LEAs appear to have been reluctant to endorse cricket for girls in the schools in their localities.

At times, the PE Inspectorate implied that there was no point spending money on cricket; girls were only interested in certain games, and cricket was not one of these. In 1959 they stated:

Interest in field games is certainly not as strong as it used to be, and Saturday matches are becoming more and more unpopular with girls who live in a society which has 'Saturday off'...Tennis and badminton are very popular and very fashionable. ${ }^{65}$

This, however, was a self-perpetuating argument. If girls were not offered cricket while at school, they did not have any opportunity to develop an interest and the sport did not become 'fashionable' in the same way that tennis did. Besides, it is clear that there was a huge untapped market of interest in the sport. Netta Rheinberg, the editor of Women's Cricket, wrote in a 1950 editorial that:

the core of my correspondence...is made up of letters from schoolgirls, or youngsters just out of school, who wish to play cricket. Some have watched a lot of cricket; some have played a bit with their brothers; some not even that - they are just 'keen' to play England's national summer game. ${ }^{66}$

Teachers also wrote to the magazine indicating that their pupils were favourably disposed to cricket when they had the opportunity to play. Miss Taylor, of Stonehouse Secondary Modern School in Gloucestershire, found that girls were 'extremely keen and practice every lunch hour...the girls have throroughly enjoyed all the matches they played...I can fully recommend [cricket in these schools]'. ${ }^{67}$ The fact that schoolgirls attended the WCA's central coaching sessions out of school hours, where these were offered, indicates a good level of interest.

An enthusiasm felt by teachers for cricket was often the difference between a school introducing it to its pupils and bypassing it completely. Unfortunately for the WCA, there appears to have been widespread teacher hostility to schoolgirl cricket in these years. Girls regularly wrote to Women's Cricket magazine complaining that, for example, 'Our school does not play cricket in the summer because our headmistress considers the game unladylike'. ${ }^{68}$ In 1958 an article was published in the Illustrated Leicester Chronicle, printing the responses of several headmistresses to the question, 'why are you reluctant to take up cricket in your schools?' Miss Thomas, the head of Gateways Girls School, responded: 'Lack of accommodation is a big factor. We've no room for girls to play cricket. Also tennis is more useful socially and more the kind of accomplishment we like for our girls'. ${ }^{69}$ One senses that the latter reason was the more important. There is evidence that some girls played in the face of opposition by their teachers; the Nottingham Girls' Grammar School Cricket Club wrote to Women's Cricket proudly proclaiming that they had formed in spite of 'adverse comment from the male population of our co-educational school', including the male staff. ${ }^{70}$ Unfortunately this was not often possible.

Even those teachers who had permitted girls at their schools to play were not necessarily espousing progressive attitudes. Holland Park School, which was established in 1958 as one of the first ever comprehensive schools in England, was affiliated to the WCA by 1960. Holland Park's headmaster was asked why girls' cricket was not compulsory at his school but rather optional and played outside of school hours. His response is worth reproducing in full:

\footnotetext{
64 Women's Cricket, 24 April 1953.

65 PE Inspectorate meeting, 21 and 22 December 1959, ED 118/16, TNA: PRO.

66 Women's Cricket, 26 May 1950.

67 Ibid., 28 August 1959.

68 Ibid., 27 April 1956.

69 Ibid., 5 September 1958.

70 Ibid., 18 September 1948.
} 
Tradition decrees that almost as soon as they can walk boys start playing cricket...For girls there is no such compulsion... They play in smaller groups than do boys and it is seldom that they are found playing team games...When they take part in organised games at school the boys readily and naturally take to organised cricket...For girls...organised games is often an introduction to team-playing...A few of them may take to cricket...but they will be a small minority, a minority which will dwindle when faced with the hazards of the hard ball - and it is no good appealing to a girl's manliness if she declines to accept a chance of catching a full-blooded drive. Girls will not enjoy a game in which they have neither aptitude nor interest. ${ }^{71}$

This is a good example of one of the trends noted by the PE Inspectorate, towards the underperformance of girls in PE lessons in mixed schools. ${ }^{72}$ The Inspectorate felt that this was probably at least partly the result of teacher attitudes: 'headmistresses seem to have a better conception than headmasters of the function of P.E...Head Masters tended to understand boys' needs better than girls'. ${ }^{73}$ Clearly there were problems with ensuring that teachers, particularly male, accepted that all physical activities, including sports like cricket, could be shared by both boys and girls. Yet even the Inspectorate, as we have seen, agreed on the necessity of secondary-level girls following a separate programme to boys. The minutes of their meetings consistently support this point; typically, it was noted in 1953 that there was a difference between '[a] girl's subjective and aesthetic approach' to PE and 'a boy's need for objective achievement and his irritation with refinement and detail'. ${ }^{74}$ This helped to justify the exclusion of cricket - as well as other sports, like football - from the schoolgirl's remit.

It does therefore appear that the main reasons why schoolgirl cricket was not introduced more widely into the new secondary modern and grammar schools were external to the WCA. The above comments show the affixed conservative attitudes to gender of those responsible for PE in schools at this time. It was these notions, and the consequent conclusion reached that cricket was not suitable or favourable as a school sport for girls, that prevented women's cricket from taking hold of the curricula of secondary modern and, later, comprehensive schools.

\section{Conclusion}

In the MCC's 1951 Book for the Young Cricketer, one of the winners of their essay competition 'Why I love Cricket' was a seventeen year old schoolgirl, Christine Maden. She wrote of the sport:

Cricket is rich and virile, and has, even in restraint, a latent strength, which may leap excitingly at that moment when the game seems dullest....In the flash of white flannels against the gleaming grass is the honest, the justice, of cricket displayed, and, to me, the remembrance of it brings patience to await the spring. ${ }^{75}$

Schoolgirls who experienced it often felt the same passion for cricket as their male counterparts. It was, after all, England's national sport.

Yet the near-death of schoolgirl cricket by the 1970s meant that the experience of participating in the sport was denied to the majority of those who attended the new secondary modern and grammar schools. There are a variety of reasons for this. Lack of facilities certainly played its part, as many LEAs were reluctant to invest in the pitches and equipment necessary for school participation in cricket, preferring to focus on activities like swimming, netball and hockey. However, much of this reluctance was also due to the entrenched conservative attitudes of the educational authorities and some teachers, who continued to oppose female participation in certain

\footnotetext{
Ibid., 12 August 1960.

72 In fact this has remained an issue. See for example Oliver Leaman, 'Sit on the sidelines and watch the boys play': sex differentiation in physical education (York: Schools Council, 1984).

73 PE Inspectorate meeting, 17 and 18 December 1953, ED 158/115, TNA: PRO.

74 Ibid.

75 John St John (ed), Book for the Young Cricketer: 99.
} 
types of overstrenous female activity, in this case cricket, after the Second World War. The best efforts of the WCA to engage with and reach out to the new secondary schools in the wake of the 1944 Education Act were therefore fruitless. As this case study has shown, in the years following the 1944 Act, the English education system remained not only divided along class lines, but on gender lines too. Indeed, the legacy of the decisions of those in authority in PE after the war is shown by the fact that PE in schools today remains gender-segregated, with very few girls able to participate in cricket. 


\section{Tables}

Table 1: Schools affiliated to the WCA in 1950 and $1960^{76}$

\begin{tabular}{|l|l|l|l|l|l|l|l|}
\hline Year & Total & $\begin{array}{l}\text { Independe } \\
\text { nt schools }\end{array}$ & $\begin{array}{l}\text { Grammar } \\
\text { schools }\end{array}$ & $\begin{array}{l}\text { Secondary } \\
\text { moderns }\end{array}$ & $\begin{array}{l}\text { Technical } \\
\text { schools }\end{array}$ & $\begin{array}{l}\text { Comprehe } \\
\text { nsives }\end{array}$ & Other \\
\hline 1950 & 82 & 38 & 33 & 0 & 1 & 0 & $10^{*}$ \\
\hline 1960 & 87 & 33 & 43 & 0 & 0 & 2 & $9 * *$ \\
\hline
\end{tabular}

*This includes 5 direct-grant schools, 1 voluntary-aided school and 2 convent schools.

**This includes 3 GPDST schools and 2 convent schools. 